\title{
Korelasi Cluster of Differentiation 4 dan Viral Load dengan Fungsi Sistolik Ventrikel Kiri pada Anak dengan Human Immunodeficiency Virus
}

Nicholas Adrian, Sri Endah Rahayuningsih, Anggraini Alam

Bagian Ilmu Kesehatan Anak Fakultas Kedokteran Universitas Padjadjaran/RSUP Dr. Hasan Sadikin, Bandung

Latar belakang. Nilai viral load dan cluster of differentiation 4 (CD4) pada infeksi human immunodeficiency virus (HIV) merupakan prediktor independen progresifitas penyakit pada usia $>5$ tahun. Infeksi HIV memengaruhi organ jantung dalam bentuk gangguan fungsi sistolik ventrikel kiri, pada awalnya dapat tanpa gejala. Penelitian ini diharapkan dapat memberikan gambaran keterlibatan kardiovaskuler pada anak dengan HIV.

Tujuan. Mengetahui korelasi antara CD4, viral load dengan fungsi sistolik ventrikel kiri pada anak dengan HIV.

Metode. Desain penelitian potong lintang, data dari register penelitian HIV bulan Januari-Februari 2020 di RSUP Dr. Hasan Sadikin. Sampel penelitian adalah anak dengan HIV usia $5-<18$ tahun. Subjek penelitian diperiksa kadar CD4 dan viral load, untuk fungsi sistolik ventrikel kiri diukur melalui fraksi ejeksi dan pemendekan fraksi dengan alat echocardiography. Analisis korelasi menggunakan uji Pearson dan Spearman sesuai distribusi data.

Hasil. Subjek penelitian adalah 60 anak dengan HIV. Nilai rata-rata CD4 (822 $\pm 380 / \mathrm{mm} 3)$. Viral load 68,3\% undetected. Nilai rata-rata pemendekan fraksi $(35,8 \pm 5 \%)$. Nilai rata-rata fraksi ejeksi $(65,7 \pm 6,8 \%)$. Hasil korelasi CD4 dengan pemendekan fraksi $(\mathrm{r}=0,19 \mathrm{p}=0,07), \mathrm{CD} 4$ dengan fraksi ejeksi $(\mathrm{r}=0,22 \mathrm{p}=0,04)$, viral load dengan pemendekan fraksi $(\mathrm{r}=-0,10 \mathrm{p}=0,20)$, dan viral load dengan fraksi ejeksi $(\mathrm{r}=-0,09 \mathrm{p}=0,22)$. Kesimpulan. Terdapat korelasi positif lemah antara CD4 dengan fraksi ejeksi, hasil penelitian mungkin dipengaruhi oleh faktor lain yang belum diteliti seperti status pengobatan pada pasien. Sari Pediatri 2021;23(2):103-9

Kata kunci: CD4, viral load, fungsi sistolik ventrikel kiri, fraksi ejeksi, pemendekan fraksi, HIV anak

\section{Correlation of Cluster of Differentiation 4 and Viral Load with Left Ventricular Systolic Function in Children with Human Immunodeficiency Virus}

Nicholas Adrian, Sri Endah Rahayuningsih, Anggraini Alam

Background. Viral load and cluster of differentiation 4 (CD4) in human immunodeficiency virus (HIV) infection were independent predictors of disease progression at age $>5$ years. HIV infection affects the heart in the form of left ventricular systolic dysfunction, which initially could be without symptoms. This study is expected to provide an overview of cardiovascular involvement in children with HIV.

Objective. To understand the correlation between CD4 cell count, viral load with left ventricular systolic function in children with HIV. Methods. Cross-sectional study design, data derived from January-February 2020 HIV research register at Dr. Hasan Sadikin General Hospital. The research subjects were children with HIV, aged $5-<18$ years. We performed CD4 and viral load examination, left ventricular systolic function was measured with ejection fraction and fractional shortening using echocardiography. Pearson and Spearman tests were performed according to data distribution.

Result. The research subjects were 60 children with HIV. Mean CD4 (822 $\pm 380 / \mathrm{mm} 3), 68.3 \%$ viral load undetected. Mean fractional shortening $(35.8 \pm 5 \%)$. Mean ejection fraction $(65.7 \pm 6.8 \%)$. Correlation analysis between CD4 and fractional shortening $(\mathrm{r}=0.19 \mathrm{p}=$ $0.07)$, CD4 with an ejection fraction $(r=0.22 p=0.04)$, viral load with fractional shortening $(r=-0.10 p=0.20)$, and viral load with ejection fraction $(\mathrm{r}=-0.09 \mathrm{p}=0.22)$.

Conclusion. There was a weak positive correlation between CD4 and ejection fraction, the results of the study may be influenced by other factors that have not been studied such as the treatment status of the patients. Sari Pediatri 2021;23(2):103-9

Keywords: CD4, viral load, left ventricle systolic function, ejection fraction, fractional shortening, HIV in children

Alamat korespondensi: Sri Endah Rahayuningsih. Departemen Ilmu Kesehatan Anak Fakultas Kedokteran UNPAD. Rumah Sakit Hasan Sadikin Bandung. Jl. Pasteur 38 Kode Pos 40161. Email: seraning@yahoo.com 
$\mathrm{P}$ enyakit infeksi human immunodeficiency virus (HIV) merupakan salah satu beban kesehatan global. Sebanyak 327.282 orang menderita HIV pada tahun 2018 di Indonesia, Provinsi Jawa Barat adalah yang terbanyak. Laporan dari sistem informasi HIV / acquired immune deficiency syndrome (AIDS) dan infeksi menular seksual di Indonesia pada tahun 2018 menyebutkan bahwa infeksi HIV terjadi sebanyak $988(2,1 \%)$ pada anak $\leq 4$ tahun, $459(1,0 \%)$ anak 5-14 tahun, dan 1434 (3,1\%) anak 15-19 tahun. ${ }^{1,2}$

Human immunodeficiency virus akan menginfeksi sel limfosit $\mathrm{T}$ cluster of differentiation 4 (CD4). Jumlah virus dihitung dengan pemeriksaan viral load. Nilai viral load dan CD4 dapat digunakan sebagai prediktor dari progresifitas HIV dan risiko mortalitas pada usia di atas 5 tahun. Perkembangan surveillance dan terapi membuat penderita HIV dapat bertahan hidup dari ancaman infeksi oportunistik dan toksisitas obat, tetapi pada akhirnya kematian dapat tetap terjadi akibat neoplasma maupun kerusakan organ. Salah satu kerusakan organ yang dapat terjadi adalah gangguan kardiovaskuler. ${ }^{3-7}$

Penyebab manifestasi gangguan kardiovaskuler pada anak dengan HIV belum dapat ditentukan, tetapi kemungkinan penyebabnya multifaktorial, di antaranya depresi sistem imun berkepanjangan, infeksi oportunistik, penggunaan obat-obatan, respon autoimun, maupun malnutrisi. Sebuah penelitian multisenter prospektif, yaitu The Prospective Pediatric Pulmonary and Cardiac Complications Study of HIV $\left(\mathrm{P}^{2} \mathrm{C}^{2}\right)$, menunjukkan bahwa gangguan kardiovaskuler banyak ditemukan pada anak dengan HIV. Gangguan kardiovaskuler ditemukan berperan langsung pada kematian $11,8 \%$ anak di bawah usia 10 tahun. Hal tersebut meningkat hingga $25 \%$ pada anak berusia 10 tahun ke atas. ${ }^{6,8,9}$

Salah satu gangguan kardiovaskuler yang dapat terjadi adalah kardiomiopati terkait HIV, yang secara luas didefinisikan sebagai penurunan fungsi sistolik ventrikel kiri, hal ini diakui sebagai komplikasi jangka panjang utama dari infeksi HIV. Fungsi sistolik ventrikel kiri dapat dinilai menggunakan echocardiography, parameter yang diukur adalah pemendekan fraksi dan fraksi ejeksi. Penelitian Arodiwe di Nigeria menemukan bahwa terdapat hubungan yang signifikan antara nilai CD4 yang lebih rendah dengan terjadinya gangguan fungsi sistolik ventrikel kiri pada anak dengan HIV. Penelitian Lipshultz (2013) di Amerika Serikat melakukan perbandingan antara 2 penelitian kohort pada anak dengan HIV, dan menemukan bahwa populasi dengan nilai CD4 yang lebih rendah dan viral load yang lebih tinggi memiliki fungsi sistolik jantung kiri yang lebih buruk. ${ }^{1,4,10-12}$

Data keterlibatan kardiovaskuler pada anak dengan HIV di Indonesia, serta hubungannya dengan kadar CD4 dan viral load belum diketahui secara pasti, sehingga hal tersebut menjadi dasar dilakukannya penelitian ini.

\section{Metode}

Penelitian ini memiliki desain analitik korelasional dengan rancangan potong lintang. Peneliti melakukan analisis korelasi antara CD4 dan viral load dengan fungsi sistolik ventrikel kiri. Subjek penelitian adalah pasien anak dengan HIV yang berobat secara rawat jalan di RSUP Dr. Hasan Sadikin periode Januari-Februari 2020 dan tercatat dalam Register Penelitian HIV KSM Ilmu Kesehatan Anak FK UNPAD/RSUP Dr Hasan Sadikin. Pemilihan subjek berdasarkan kriteria inklusi dan eksklusi. Kriteria inklusi adalah anak berusia lebih dari 5 tahun dan kurang dari 18 tahun serta anak telah terdiagnosis HIV. Kriteria eksklusi adalah memiliki kelainan jantung bawaan, memiliki kelainan irama jantung, dan memiliki kelainan pada katup jantung. Data penelitian diambil dari Register Penelitian HIV KSM Ilmu Kesehatan Anak FK

UNPAD/RSUP Dr Hasan Sadikin yang telah terisi lengkap. Semua subjek penelitian yang memenuhi kriteria inklusi dilakukan pencatatan data, yaitu nomor urut penelitian, jenis kelamin, usia, CD4, viral load, dan fungsi sistolik ventrikel kiri yang diukur melalui echocardiography dalam bentuk fraksi ejeksi dan pemendekan fraksi. ${ }^{11}$ Pemilihan subjek dilakukan secara total sampling, yaitu semua subjek yang memenuhi kriteria pemilihan dimasukkan ke dalam penelitian sampai jumlah subjek terpenuhi. Penelitian ini telah mendapatkan persetujuan etik dari Komite Etik Penelitian RSUP Dr Hasan Sadikin dengan nomor LB.02.01/X.6.5/366/2020 dan surat izin penelitian dari RSUP Dr. Hasan Sadikin dengan nomor LB.02.01/X.2.2.1/2273/2021. Analisis data dilakukan dengan korelasi Pearson test bila data berdistribusi normal atau dengan Spearman jika data tidak berdistribusi normal, menggunakan program Statistical Product and Service Solution (SPSS) for Windows versi 20.0. 


\section{Hasil}

Peneliti mendapatkan total 60 subjek penelitian berusia 5 hingga $<18$ tahun dari Register Penelitian HIV KSM Ilmu Kesehatan Anak FK UNPAD/RSUP Dr Hasan Sadikin, sebagian besar subjek berjenis kelamin laki-laki $(\mathrm{n}=32,53,2 \%)$. Usia rata-rata subjek penelitian adalah $10,8 \pm 3,5$ tahun.
Tabel 1 menunjukkan bahwa CD4, pemendekan fraksi dan fraksi ejeksi berdistribusi normal, CD4 memiliki rata-rata $822 \mathrm{sel} / \mathrm{m}^{3}$ dengan simpangan baku sebesar $380 \mathrm{sel} / \mathrm{m}^{3}$, pemendekan fraksi memiliki nilai rata-rata $35,8 \%$ dengan simpangan baku $5,0 \%$ dan fraksi ejeksi memiliki nilai rerata $65,7 \%$ dengan simpangan baku 6,8\%. Viral load tidak berdistribusi

Tabel 1. CD4, viral load, pemendekan fraksi, dan ejeksi fraksi

\begin{tabular}{|c|c|c|}
\hline \multirow{2}{*}{\multicolumn{3}{|c|}{$\begin{array}{l}\text { Variabel } \\
\left.\text { CD4 (sel/mm } / \mathrm{mm}^{3}\right)\end{array}$}} \\
\hline & & \\
\hline Rerata $\pm S D$ & $822 \pm 380$ & Normal \\
\hline \multicolumn{3}{|c|}{ Viral load (copies $/ \mathrm{mm}^{3}$ ) } \\
\hline Min-Maks & $0-316214$ & Tidak Normal \\
\hline \multicolumn{3}{|c|}{ Pemendekan fraksi (\%) } \\
\hline Rerata $\pm S D$ & $35,8 \pm 5,0$ & Normal \\
\hline \multicolumn{3}{|c|}{ Fraksi ejeksi (\%) } \\
\hline Rerata $\pm S D$ & $65,7 \pm 6,8$ & Normal \\
\hline
\end{tabular}

Tabel 2. Korelasi antara CD4, viral load dengan pemendekan fraksi

\begin{tabular}{lcccccc}
\hline & \multicolumn{3}{c}{ Korelasi dengan pemendekan fraksi } & \multicolumn{3}{c}{ Korelasi dengan fraksi ejeksi } \\
\cline { 2 - 7 } & $\mathrm{r}$ & $95 \% \mathrm{CI}$ & Nilai $\mathrm{p}$ & $\mathrm{R}$ & $95 \%$ CI & Nilai p \\
\hline CD4 & $0,192^{\mathrm{a}}$ & $-0,135-0,362$ & 0,071 & $0,225^{\mathrm{a}}$ & $-0,135-0,362$ & $0,042^{*}$ \\
Viral load & $-0,108^{\mathrm{b}}$ & $-0,372-0,124$ & 0,205 & $-0,099^{\mathrm{b}}$ & $-0,372-0,124$ & 0,226 \\
\hline
\end{tabular}

Keterangan: Analisis menggunakan korelasi ${ }^{\mathrm{a}}$ pearson, ${ }^{\mathrm{b}}$ rank Spearman, ${ }^{*}$ signifikan

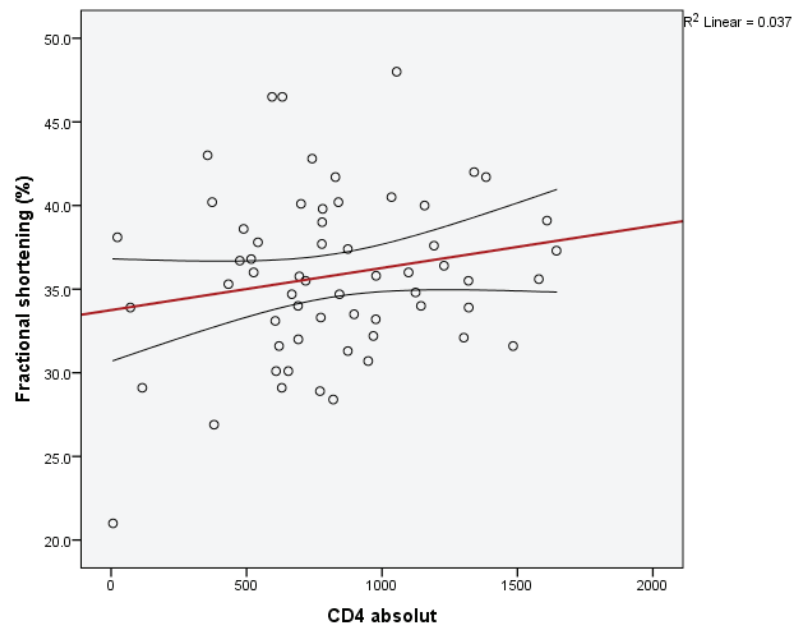

Gambar 1. Scatterplot CD4 dengan pemendekan fraksi

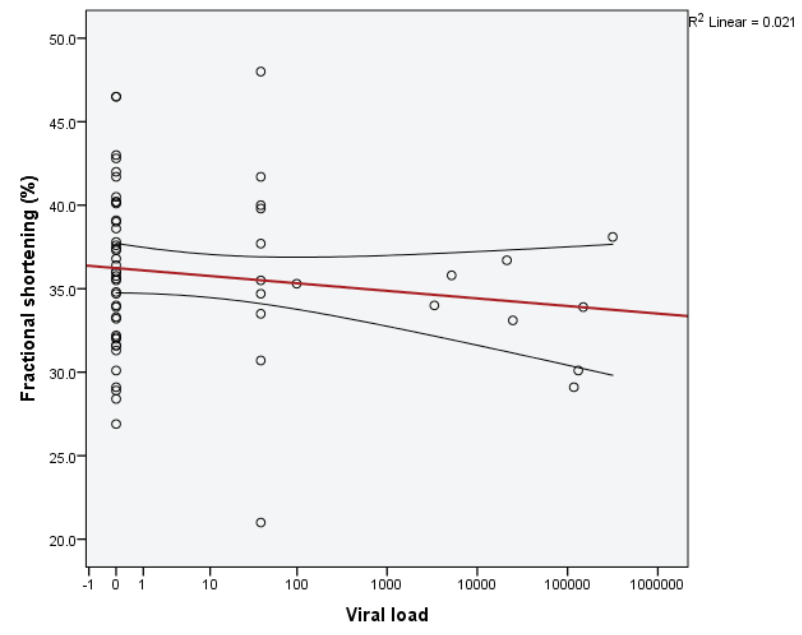

Gambar 2. Scatterplot viral load dengan pemendekan fraksi 


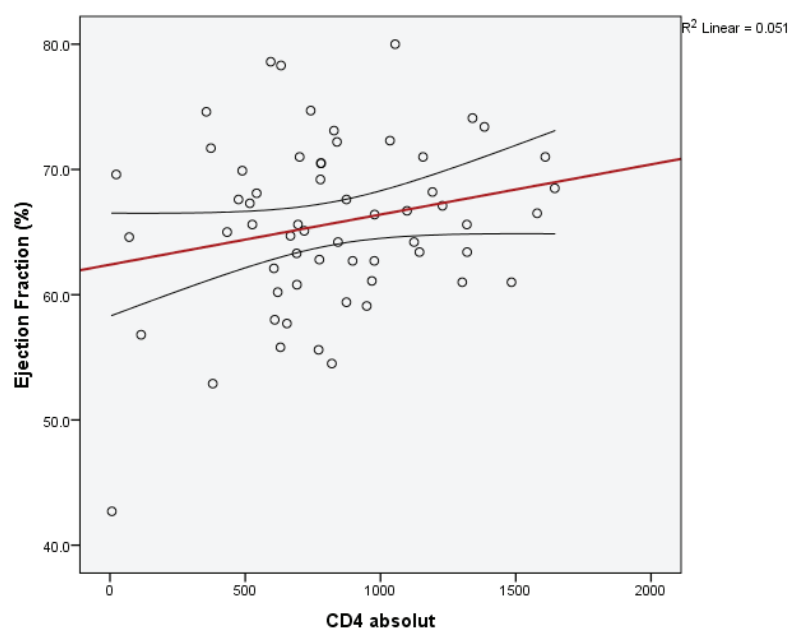

Gambar 3. Scatterplot CD4 dengan fraksi ejeksi

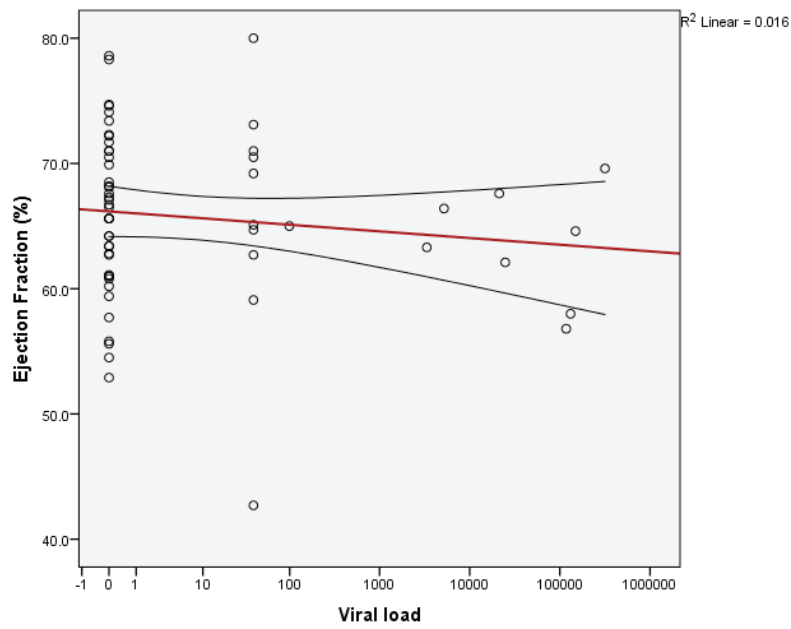

Gambar 4. Scatterplot viral load dengan fraksi ejeksi

normal dan memiliki rentang $0-316214$ copies $/ \mathrm{mm}^{3}$. Nilai viral load sebagian besar $(68,3 \%)$ undetected.

Tabel 2 menunjukkan bahwa tidak terdapat korelasi antara CD4 dan viral load dengan pemendekan fraksi ( $p>0,05)$ masing-masing memiliki koefisien korelasi sebesar 0,192 dan -0,108. Tabel 2 juga menunjukkan bahwa terdapat korelasi positif lemah antara CD4 dengan fraksi ejeksi $(p<0,05)$, koefisien korelasi sebesar 0,225 . Peneliti tidak menemukan korelasi antara viral load dengan fraksi ejeksi ( $>0,05)$, koefisien korelasi sebesar -0,099. 


\section{Pembahasan}

Progresifitas penyakit akan bertambah seiring dengan peningkatan defisiensi imun (penurunan CD4), infeksi oportunistik, dan komplikasi lainnya yang berkaitan dengan HIV, terutama pada kondisi nilai CD4 di bawah 200/mm3. Pasien dengan kadar viral load sangat tinggi (di atas 100.000 copies/ $\mathrm{ml}$ ) akan mengalami penurunan sel CD4 lebih cepat. Nilai rata-rata CD4 dan viral load anak dengan HIV bervariasi pada beberapa penelitian. Salah satu contoh adalah $\mathrm{Hsue}^{17}$ yang menemukan nilai rata-rata CD4 $420 \mathrm{sel} / \mathrm{mm}^{3}$ dan viral load 63\% undetected. Reinsch ${ }^{18}$ menemukan nilai rata-rata CD4 $509 \pm 301 \mathrm{sel} / \mathrm{mm}^{3}$, untuk viral load $66 \%$ undetected. Arodiwe dkk ${ }^{1}$ mendapatkan nilai rata-rata CD4 504,6 $\pm 300,3 \mathrm{sel} / \mathrm{mm}^{3}$. Penelitian ini mendapatkan nilai ratarata CD4 $822 \mathrm{sel} / \mathrm{mm}^{3} \pm 380 \mathrm{sel} / \mathrm{mm}^{3}$, dari 60 subjek hanya terdapat $10(16,6 \%)$ subjek dengan nilai CD4 $<500 / \mathrm{mm}^{3}$ dan hanya $4(6,6 \%)$ subjek dengan nilai CD $4<200 / \mathrm{mm}^{3}$. Nilai CD4 pada penelitian ini lebih tinggi bila dibandingkan penelitian Hsue, Reinsch, dan Arodiwe. Nilai viral load pada penelitian ini sebagian besar $(68,3 \%)$ undetected. Sementara untuk nilai viral load pada penelitian ini serupa dengan penelitian Hsue dan Reinsch.

Gangguan kardiovaskuler pada pasien HIV, salah satu di antaranya adalah kardiomiopati terkait HIV. Secara luas didefinisikan sebagai penurunan fungsi sistolik ventrikel kiri atau dilatasi ventrikel kiri yang dibuktikan oleh pencitraan, dengan atau tanpa gejala gagal jantung. Temuan tersebut saat ini dianggap sebagai komplikasi jangka panjang utama dari infeksi HIV. Kardiomiopati terkait HIV kemungkinan penyebabnya multifaktorial. Penyebab-penyebab yang dipertimbangkan termasuk infeksi langsung miokardium oleh virus HIV dengan atau tanpa miokarditis, toksisitas dari obat yang digunakan untuk mengobati infeksi HIV, infeksi oportunistik, serta gangguan gizi. Human immunodeficiency virus dapat menyebabkan aktivasi imun sistemik yang tidak teratur yang menyebabkan peradangan kronis, mekanisme ini diduga berkontribusi terhadap kerusakan organ. Sel miosit janin manusia mampu melakukan fagositosis HIV melalui reseptor Fc spesifik meskipun tidak ada reseptor CD4. Infeksi HIV dalam sel interstitial jantung memainkan peran patogenik yang penting karena sel-sel yang terinfeksi ini berfungsi sebagai tempat penyimpanan virus serta sel-sel penyaji antigen yang kemudian melakukan mediasi peradangan. Sitokin proinflamasi, terutama IL dan TNF, telah terbukti memberikan efek inotropik negatif dan kemungkinan memainkan peran dalam kardiomiopati terkait HIV, khususnya gangguan fungsi sistolik ventrikel kiri. Gangguan fungsi sistolik ventrikel kiri dapat dinilai salah satunya melalui pemeriksaan echocardiography, parameter yang diukur adalah pemendekan fraksi dan fraksi ejeksi. ${ }^{1-4,19-22}$

Nilai pemendekan fraksi dan fraksi ejeksi bervariasi pada beberapa penelitian, di antaranya adalah penelitian Hsue $^{17}$ dengan nilai fraksi ejeksi $33-49 \%$, Reinsch ${ }^{18}$ dengan nilai fraksi ejeksi $20-54 \%$, Badal ${ }^{3}$ dengan nilai pemendekan fraksi $33,4 \pm 6,41 \%$ dan fraksi ejeksi $60,7 \pm 6,54 \%$, serta Arodiwe $\mathrm{dkk}^{1}$ dengan nilai pemendekan fraksi 31,6-35,3\% dan fraksi ejeksi $45,3-53,3 \%$. Nilai rata- rata pemendekan fraksi pada penelitian ini adalah $35,8 \% \pm 5,0 \%$ serta fraksi ejeksi $65,7 \% \pm 6,8 \%$. Penelitian ini hanya menemukan 2 $(3,3 \%)$ subjek dengan penurunan fungsi sistolik ventrikel kiri, dengan rincian 1 subjek memiliki nilai pemendekan fraksi $21 \%(<28 \%)$ dan ejeksi fraksi $42,7 \%$ $(<45 \%)$ serta 1 subjek memiliki nilai pemendekan fraksi $26,9 \%(<28 \%)$. Hal ini menunjukkan fungsi sistolik ventrikel kiri pada penelitian ini hampir seluruhnya masih dalam batas normal. Nilai pemendekan fraksi pada penelitian ini sesuai dengan penelitian $\mathrm{Badal}^{3}$ dan Arodiwe $\mathrm{dkk}^{1}$. Nilai rata-rata fraksi ejeksi pada penelitian ini lebih baik dibandingkan penelitian Hsue $^{17}$, Reinsch ${ }^{18}$, dan Arodiwe dkk ${ }^{1}$.

Hasil analisis tidak mendapatkan korelasi antara CD4 dan viral load dengan pemendekan fraksi. Hasil analisis juga tidak mendapatkan korelasi antara viral load dengan fraksi ejeksi, tetapi terdapat korelasi positif lemah antara CD4 dengan fraksi ejeksi, koefisien korelasi sebesar 0,225, artinya semakin tinggi CD4 maka akan semakin tinggi fraksi ejeksi. Kohort $\mathrm{P}^{2} \mathrm{C}^{2}$ menemukan bahwa nilai CD4 yang lebih tinggi berhubungan dengan fungsi sistolik jantung yang lebih baik, hal ini sesuai dengan temuan penelitian ini. Analisis gabungan kohort AMP dan $\mathrm{P}^{2} \mathrm{C}^{2}$ mendapatkan bahwa anak dengan $\mathrm{CD} 4$ $<15 \%$ dan viral load $>5000$ copies $/ \mathrm{ml}$ memiliki fungsi sistolik jantung yang lebih rendah secara signifikan. Hasil analisis pada penelitian ini mungkin dipengaruhi oleh status imunologis subjek penelitian yang relatif baik. Hal tersebut mungkin disebabkan oleh subjek penelitian yang pengobatannya berjalan dengan baik (faktor kombinasi ART maupun kepatuhan minum 
obat yang baik), tetapi faktor pengobatan subjek belum dimasukkan ke dalam analisis penelitian ini. ${ }^{4,6}$

Keterbatasan penelitian ini, yaitu desain studi berupa potong lintang yang tidak dapat mencari hubungan sebab akibat, echocardiography hanya dilakukan satu kali per subjek sehingga tidak dapat menggambarkan perubahan fungsi jantung, belum dilakukan analisis efek dari perbedaan ART tiap individu, belum diperhitungkan faktor kepatuhan minum obat, serta penelitian ini belum melihat fungsi jantung secara keseluruhan. Sebuah studi oleh Lipshultz ${ }^{4,6}$ membandingkan antara subjek pada kohort adolescent master protocol (AMP) dan $\mathrm{P}^{2} \mathrm{C}^{2}$. Pemendekan fraksi secara signifikan lebih rendah pada populasi kohort $\mathrm{P}^{2} \mathrm{C}^{2}$. Hal ini menunjukkan fungsi jantung yang lebih buruk pada populasi kohort $\mathrm{P}^{2} \mathrm{C}^{2}$ yang merupakan studi sebelum era HAART, sedangkan pada kohort AMP (studi yang dilakukan setelah era HAART) subjeknya memiliki kadar CD4 dan viral load, serta fungsi jantung yang lebih baik. Parameter penurunan pemendekan fraksi pada kohort $\mathrm{P}^{2} \mathrm{C}^{2}$ merupakan prediktor mortalitas pasien, tetapi hal ini tidak berlaku setelah era HAART sehingga hal tersebut mendukung efek kardioprotektif dari HAART. Hal ini mungkin disebabkan oleh beberapa faktor, seperti status imunologis yang lebih baik pada era HAART, pertumbuhan somatik yang lebih normal, efek langsung HAART terhadap HIV pada intramiokardium, atau mekanisme lain yang belum diketahui. Hal ini menunjukkan bahwa karakteristik pengobatan yang diterima pasien, baik dari jenis obat maupun kepatuhan minum obat penting untuk diteliti.

Kohort AMP menemukan fungsi jantung yang baik dibandingkan kohort $\mathrm{P}^{2} \mathrm{C}^{2}$, tetapi setelah lebih dari 10 tahun terapi, fungsi jantung cenderung mulai menurun, hal ini menunjukkan tetap diperlukannya pemantauan jantung berkala pada anak dengan HIV.

\section{Kesimpulan}

Peneliti menemukan korelasi positif lemah antara CD4 dengan fungsi sistolik ventrikel kiri, tetapi tidak terdapat korelasi antara viral load dengan fungsi sistolik ventrikel kiri. Hasil penelitian ini mungkin dipengaruhi oleh faktor lain yang belum dipertimbangkan, seperti faktor kepatuhan minum obat yang baik. Gangguan fungsi jantung merupakan temuan penting yang dapat ditemukan dengan bantuan pemeriksaan penunjang, seperti echocardiography meski belum terdapat gejala klinis. Dengan demikian, pemantauan fungsi jantung secara berkala diperlukan pada anak dengan HIV.

\section{Daftar pustaka}

1. Arodiwe I, Ikefuna A, Obidike E, dkk. Left ventricular systolic function in Nigerian children infected with HIV/AIDS: a cross-sectional study. CVJA 2016;27:25-9.

2. Kementerian Kesehatan Republik Indonesia. Laporan Perkembangan HIV-AIDS \& Infeksi Menular Seksual (IMS) Triwulan IV Tahun 2018. Jakarta: Kemkes RI; 2019.

3. Badal S, Gupta R, Kumar P, Sharma M, Chhajta D. Cardiac manifesta-tions in HIV infected children. Are they under diagnosed. HIV/AIDS Res Treat Open J 2015;2:21-6.

4. Lipshultz SE, Williams PL, Wilkinson JD, dkk. Cardiac status of HIV infected children with long term combination of antiretroviral therapy: results from the Adolescent Master Protocol of the Multicenter Pediatric HIV/AIDS Cohort Study. JAMA Pediatrics 2013;167:520-7.

5. Karen J. Human immunodeficiency virus and acquire immunodeficiency syndrome. Dalam: Kliegman R, Marcdante K J, and Behrman R.E, penyunting. Nelson Essentials of Pediatric. Edisi ke-15. Philadelphia: Elsevier Saunders; 2006.h....

6. Lipshultz SE, Easley KA, Orav EJ, dkk. Cardiac dysfunction and mortality in HIV-infected children: the prospective $\mathrm{P}^{2} \mathrm{C}^{2} \mathrm{HIV}$ multicentre study: pediatric pulmonary and cardiovascular complications of vertically transmitted human immunodeficiency virus $\left(\mathrm{P}^{2} \mathrm{C}^{2} \mathrm{HIV}\right)$ study group. Circulation 2000;102:1542-8.

7. Nasronudin. HIV dan AIDS pendekatan biologi molekuler klinis dan sosial. Edisi ke-2. Surabaya: Airlangga University Press; 2013.

8. Singh P, Hemal A, Agarwal S, Kumar D. Cardiac manifestations in HIV infected children. Indian J Pediatr 2015;82:230-4.

9. Pongprot Y, Sittiwangkul R, Silvilairat S, Sirisanthana V. Cardiac manifestations in HIV-infected Thai children. Ann Trop Paediatr 2004;24:153-9.

10. Panel on Antiretroviral Therapy and Medical Management of Children Living with HIV. Guidelines for the use of antiretroviral agents in pediatric HIV infection. [diunduh 28 Oktober 2020]. Didapat dari: http:/laidsinfo.nih.gov/ contentfles/lvguidelines/pediatricguidelines.pdf.

11. Myung KP, Salamat M. Noninvasive imaging tools. Dalam: Pediatric Cardiology for Practitioners. Edisi ke-7. 2021.h. 65-6.

12. Remick J, Georgiopoulou V, Marti C, dkk. Heart failure in patients with human immunodeficiency virus infection: epidemiology, pathophysiology, treatment, and future research. Circulation 2014;129:1781-9.

13. Seitz R. Human immunodeficiency virus (HIV). Transfus Med Hemother 2016;43:203-22. 
14. Zimbabwe Go. Zimbabwe National HIV and AIDS Strategic Plan (ZNASP) 2006-2010. National AIDS Council Harare; 2006.

15. Alain B. Leucocyte typing: human leucocyte differentiation antigens detected by monoclonal antibodies: specification, classification, nomenclature. Berlin: Springer; 1984.

16. World Health Organization. WHO case definition of HIV for surveillance and revised clinical staging and immunological classification of HIV-related disease in adults and children [internet]. 2007. [diunduh Desember 2020]. Didapat dari: http//www.who.int/hiv/pub/guidelines/HIVstaging 150307.pdf.

17. Hsue PY, Hunt PW, Ho JE, dkk. Impact of HIV infection on diastolic function and left ventricular mass. Circ Heart Fail 2010;3:132-9.

18. Reinsch N, Kahlert P, Esser S, dkk. Echocardiographic findings and abnormalities in HIV-infected patients: results from a large, prospective, multicenter HIV-heart study. Am J Cardiovasc Dis 2011;1:176-84.

19. Lewis W. AIDS cardiomyopathy: physiological, molecular, and biochemical studies in the transgenic mouse. Ann N Y Acad Sci 2001;946:46-56.

20. Al-Naami G, Kiblawi F, Kest H, Hamdan A, Myridakis D. Cardiac mechanics in patients with human immunodeficiency virus: a study of systolic myocardial deformation in children and young adults. Pediatr Cardiol 2014;35:1046-51.

21. Patel K, Van Dyke RB, Mittleman MA, Colan SD, Oleske JM, Seage GR, 3rd. The impact of HAART on cardiomyopathy among children and adolescents perinatally infected with HIV-1. AIDS 2012;26:2027-37.

22. Monsuez JJ, Escaut L, Teicher E, Charniot JC, Vittecoq D. Cytokines in HIV-associated cardiomyopathy. Int J Cardiol 2007;120:150-7. 